ZUZANNA ZBRÓG

Uniwersytet Jana Kochanowskiego

w Kielcach

\title{
ZBIOROWE PISANIE BIOGRAFII JAKO METODA UCZENIA SIĘ O SOBIE, O INNYCH, O ŚWIECIE
}

\begin{abstract}
AвSTRACt. Zbróg Zuzanna, Zbiorowe pisanie biografii jako metoda uczenia się o sobie, o innych, o świecie [Collective Biography Writing as a Method of Learning about Oneself, the Others and the World]. Studia Edukacyjne nr 46, 2017, Poznań 2017, pp. 357-372. Adam Mickiewicz University Press. ISSN 1233-6688. DOI: $10.14746 /$ SE.2017.46.23

The article presents an example of poststructuralist interpretation of biography episode written by students on the topic: "Becoming someone". The poststructuralist analysis focuses on the perception of the subject-in-process, requires destabilization ofrational stable andunifiedconcepts. It aims at researching the functions and results of regularities of a process in case of author's own research - the process of becoming a teacher in classes I-III. People engaged in CBW have a chance to understand their own situation by trying to answer the questions concerning what we really know about ourselves and the reality. The article discusses chosen theoretical assumptions and elements of the methodological procedure applied in the method of collective biography writing. The article is closed with remarks for the work with students which were verified in practice. This may help other researchers when they start working with this method.
\end{abstract}

Key words: collective biography writing, students-future early school education teachers, memories analysis

\section{Wstęp \\ - podstawowe założenia metody zbiorowego pisania biografii}

Zbiorowe pisanie biografii $(\mathrm{ZPB})^{1}$ dotyczy wspólnego konstruowania narracji bazujących na wspomnieniach osobistych. Nazwa metody została utworzona z przenośnego zestawienia pojęć o przeciwstawnym, wykluczają-

1 Dziękuję Pani Prof. Monne Wihlborg z Uniwersytetu w Lund za udostępnienie wielu interesujących materiałów na temat zbiorowego pisania biografii, dzięki którym mogłam rozpocząć pracę tą metodą. 
cym się wzajemnie znaczeniu. Termin „zbiorowa biografia” opisuje zarówno metodę pracy z osobistymi wspomnieniami, jak i oksymoroniczne implikacje epitetu wysuwające na pierwszy plan napięcie między jednostką (jej biografią) a kolektywem, które jest jednocześnie istotą metody. Biografia kojarzy się nam zwykle z przebiegiem życia danej osoby od dzieciństwa do dorosłości. W ZPB mamy natomiast do czynienia jedynie z epizodem biograficznym, najpierw opowiadanym, potem zapisywanym i ponownie redagowanym pod wpływem rozmów z członkami zespołu - współpracującej ze sobą grupy, która dąży do tego, aby opowieść była wypełniona szczegółami nacechowanymi emocjonalnie. Taki tryb pisania wspomnień wynika z ustaleń poczynionych w badaniach nad pamięcią autobiograficzną, które udowadniają, że nie tylko prowadzi on do lepszego przy pomnienia sobie epizodu biograficznego, ale powoduje, że inni, emocjonalnie zaangażowani uczestnicy warsztatów ZPB, przeżywają to samo, co narrator (kulturowa wspólnota wzorców odczuwania). Opowieść staje się wówczas zarówno intensywnie rzeczywista, jak i zdeindywidualizowana. Może $w$ takich chwilach dochodzić do autentycznego „poruszenia” ciała, na przykład płaczu, drżenia, mdłości, fizycznego odczuwania strachu, smutku, radości u wszystkich/większości członków grupy $^{2}$.

ZPB koncentruje się zasadniczo na społecznej konstrukcji własnego Ja, na jego zmianie/ przemianie, dzięki której mamy możliwość stania się krytycznie świadomymi siebie w celu zakwestionowania tego, co jest brane za pewnik, $\mathrm{w}$ celu zdarcia $\mathrm{z}$ opowiadanych historii warstwy narzuconej nam przez kulturę (stereotypy, schematy myślowe, metafory itp.) po to, aby przekonać się, jakie dyskursy społeczne nami kierują, jak funkcjonujemy jako (autonomiczne) podmioty w ramach obecnych praktyk społecznych. Wpływy społeczne, które nas pozycjonują $\mathrm{w}$ określonych bytach, powodują, że funkcjonujemy $\mathrm{w}$ pewnych okowach naszych przekonań. Ponowna ich interpretacja pomaga na nowo skonstruować nasze rozumienie siebie.

Autorzy promujący takie podejście badawcze w niedawno opublikowanych pracach na temat tej metody koncentrują się najczęściej na procesie uczenia się, eksponując przydatność ZPB zwłaszcza w eksploracji na nowo zagadnień związanych ze sprawiedliwością, równością i różnorodnością (w tym wielokulturowością), a także byciem, stawaniem się, tworzeniem siebie w kontekście edukacji i nauki (głównymi beneficjentami metody są studenci i nauczyciele akademiccy). Celem tego artykułu jest pokazanie, jakiego typu dane generuje zbiorowe pisanie biografii i jak wygląda poststrukturalistyczna interpretacja tej narracji, w której ważne jest zwłaszcza zwrócenie uwagi na kontekstowość uczenia się.

2 B. Davies, S. Gannon, Collective Biography and the Entangled Enlivening of Being, International Review of Qualitative Research, 2012, 5, 4, s. 359. 


\section{Konceptualna baza metody ZPB}

Literatura z dziedziny teorii reprezentacji społecznych podkreśla, że cała nasza wiedza (także o sobie) jest konstruowana społecznie przez daną zbiorowość i jej zdobycie nie jest indywidualnym, wewnętrznym procesem, ale procesem społeczno-interakcyjnym. $W$ procesie socjalizacji człowiek uczy się sposobów rozumienia i interpretowania świata dominujących w grupie, w której na co dzień funkcjonuje. Tak więc jednostka nie rozwiązuje każdego napotkanego problemu samotnie i samodzielnie - rozwiązania i metody są jej już zapewnione przez zbiorowość kulturową, są mentalnie zdeterminowane (jako schematy myślowe), ponieważ wynikają ze zbiorowej pamięci społeczności ${ }^{3}$.

Wyniki badań nad zbiorową pracą ze wspomnieniami prowadzone przez Friggę Haug ${ }^{4}$ oraz analizy Bradego Wagonera ${ }^{5}$ na temat nośników pamięci zbiorowej (reprezentacji społecznych) potwierdzają, że jesteśmy wspólnie zaangażowani w rozwój poznania, bycia oraz stawania się (tworzenia siebie). Tak więc również indywidualne doświadczenia są społecznie wytwarzane, zatem podlegają uniwersalizacji.

Wybór ZPB jako praktyki badawczej oznacza uświadomienie sobie, że wpływają na nas wszelkie ramy metodologiczne i teoretyczne, z których korzystamy w trakcie badania. Dyskurs społeczny, którego jesteśmy częścią, odgrywa tutaj ważną rolę, ponieważ kształtuje ludzi i tworzy własne realia oraz zrozumienie tych realiów. W związku z tym dla badacza stosującego ZPB wyzwaniem staje się bycie bardziej świadomym, w jakim zakresie faktycznie stajemy się "zaślepieni dyskursem”, nie zauważając tym samym możliwych sposobów rozumienia tego co się dzieje. Przyjęcie określonej pozycji w badaniu, punktu widzenia nakierowanego na narrację z własnej perspektywy, nieuchronnie prowadzi do tego, że widzimy świat właśnie z punktu widzenia swojej pozycji. Poszczególne obrazy, metafory, fabuły i pojęcia widziane są przez nas w kontekście określonej praktyki dyskursywnej, w której są one umiejscowione ${ }^{6}$.

${ }^{3}$ S. Moscovici, Social Representations. Explorations in Social Psychology, Cambridge 2000.

${ }^{4}$ F. Haug, za: J. Onyx, J. Small, Memory-Work: The Method, Qualitative Inquiry, 2001, 7, 6, s. 775 .

5 B. Wagoner, Collective remembering as a process of social representation, [w:] The Cambridge Handbook of Social Representations, red. G. Sammut, E. Andreouli, G. Gaskell, J. Valsiner, Cambridge 2015.

${ }^{6}$ M. Wihlborg, An Awareness of the Feminist Subject: An Example of Collective Biography Writing in Poststructuralist Discourse Practice, [w:] International Handbook of Interpretation in Educational Research, red. P. Smeyers, D. Bridges, N.C. Burbules, M. Griffiths, Dordrecht - Heidelberg - New York - London 2015, s. 274. 
Zgodnie z jedną z najbardziej znaczących współczesnych teorii dotyczącej samoświadomości - teorią Thomasa Metzingera - nie jesteśmy przyczyną naszych działań i decyzji. Istnieje jedynie model siebie, który jest procesem doświadczania siebie, dającym nam poczucie bycia kimś, a co najważniejsze - sami „nie możemy dostrzec, że stanowimy model, ponieważ jest on przezroczysty dla naszego poznania - poznajemy i doświadczamy dzięki niemu i poprzez niego"7. Grupa innych ludzi jest nam więc potrzebna, abyśmy mogli wyzwolić się z fikcji siebie, ze złudzeń odnoszących się do nas samych, abyśmy mogli poznać siebie, a poznając siebie, zaczęli rozumieć, kim jesteśmy, dlaczego zachowujemy się w ten, a nie inny sposób, jakie siły/dyskursy wpływają na nas. Poznając siebie, zaczniemy rozumieć lepiej, jaki jest świat. Pracując metodą CBW, mamy możliwość ujawnienia sposobów rozumienia siebie i innych oraz uświadomienia sobie "co naprawdę dzieje się w naszym życiu i to, jakie inne rzeczywistości możemy w nim znaleźć" 8 .

\section{Kontekst badawczy}

Zbyt częste powtarzanie w literaturze pedagogicznej znanych narracji i motywów zachowania się, niezależnie czy dotyczą one formalnego czy nieformalnego uczenia się, zwykle zaprzecza różnorodności motywów postępowania pedagogicznego. Nie pozostawia wiele miejsca na eksplorację tematu. Zakłócenie tego co znane, co uznawane jest powszechnie za prawdę lub oczywistość wymaga zastosowania odpowiedniej metodyki badania. ZPB wydaje się w tym wypadku metodą adekwatną, ponieważ poprzez zbiorowy proces przenoszenia narracji poza opowiadaną historię może wygenerować takie ujęcia tematu, które pozwolą na poststrukturalne interpretacje różnych edukacyjnych sytuacji. Ucieleśniony (osadzony w detalach) i emocjonalny charakter opowieści, potęgowany przez głośne ich odczytywanie, jest wrażliwą bazą danych, która umożliwia i zachęca badacza do zadawania pytań i odkrywania uznanej za pewnik wiedzy ${ }^{9}$.

Badania własne skoncentrowane były na nierównych relacjach komunikacyjnych między nauczycielami - opiekunami praktyk i studentami. Pozycja władzy, jaką reprezentują niektórzy nauczyciele wiąże się z niedobrymi praktykami kulturowymi/dydaktycznymi, które nadal mają miejsce w szkołach i przedszkolach, z dawaniem studentom archaicznych i szkodliwych wzorców bycia nauczycielem oraz umniejszaniem pozycji praktykanta w procesie

\footnotetext{
${ }^{7}$ J. Neckar, Samowiedza i jej bohater, [w:] Poznaj samego siebie, red. A. Niedźwieńska, J. Neckar, Warszawa 2009, s. 18.

${ }^{8}$ M. Wihlborg, An Awareness of the Feminist Subject, s. 274.

9 Tamże, s. 269.
} 
wczesnej profesjonalizacji. Jeśli przyjmiemy, że taka nierówność istnieje, jej efektywne badanie możliwe jest z wykorzystaniem metod, które odkrywają, ujawniają różne sposoby doświadczania i rozumienia tej problematyki.

Przeżywanie określonej sytuacji w trakcie uczenia się obfituje w spostrzeżenia, które mogą dość dobrze naświetlić problematykę związaną z bardziej formalnymi sytuacjami uczenia się zawodu nauczyciela. Dzięki wspólnej, zbiorowej pracy nad narracjami mamy możliwość uświadomienia sobie, jak budowana jest wiedza o byciu/stawaniu się nauczycielem. W związku z tym można uznać ten sposób pracy na zajęciach ze studentami za ważne narzędzie - metodę, która zapewne także w polskiej rzeczywistości okaże się istotna w badaniach edukacyjnych. Według wiedzy autorki, ZPB jest metodą nieznaną w obszarze badań społecznych i humanistycznych nie tylko w Polsce, ale także w Europie Środkowo-Wschodniej.

\section{Uczenie się przez oduczanie}

Narracja przedstawiana poniżej jako przykład opowieści kolektywnie wypracowanej przez grupę była częścią badań własnych zrealizowanych ze studentkami III roku pedagogiki wczesnoszkolnej i przedszkolnej, odnoszących się do procesu uczenia się bycia nauczycielem/stawania się nauczycielem $w$ warunkach pozauczelnianych ${ }^{10}$. Szerszy cel badań wychodzi poza sam proces uczenia się i dotyczy dowiadywania się o sobie czegoś więcej poprzez akceptację ram, płaszczyzn, różnych wątków i nieujawnionych obszarów naszych przekonań, które nas definiują. Nie chodzi tu o rozstrzyganie, czy nasze poprzednie doświadczenia są dobre lub złe. Chodzi o otwarcie się na nowe interpretacje, na odkrywanie czegoś, co leży poza naszym osądem, poza stwierdzeniem, że coś jest słuszne lub niesłuszne, dobre lub złe. Chodzi o uczenie się przez oduczanie ${ }^{11}$. ZPB może nam pomóc w procesie oduczania się bezwiednego postępowania zgodnie ze schematami, które nami kierują, może wspomóc nas w odejściu od pewnych mechanizmów, które mamy zinternalizowane.

Nie jest możliwe pokazanie całości tego procesu, ale można uwidocznić, jak wygląda zakończona interpretacja jednej narracji po jej opracowaniu metodą ZPB. Nacisk położony jest $w$ niej - jak pamiętamy - na proces stawania się nauczycielem i uczenie się, na zrozumienie historii w stosunku do poszukiwań i konstytucji podmiotu.

10 Dziękuję Pani Profesor Marii Czerepaniak-Walczak za metodologiczne konsultacje i zwrócenie mi uwagi, że ZPB można traktować przede wszystkim jako metodę uczenia się.

${ }^{11}$ C. Mias, Training and Ruptures, [w:] Education, Professionalization and Social Representations, red. M. Chaib, B, Danermark, S. Selander, New York - London 2013. 
Celem uczenia się jest więc świadome stawanie się przez proces odkrywania i poszukiwania tego, co ukryte oraz rozwijanie / realizacja postawy krytycznej, która z kolei stanowi fundamentalną zdolność do uczenia się w edukacji i badaniach edukacyjnych ${ }^{12}$.

\section{Stawanie się (autonomicznym) podmiotem}

Własne podejście badawcze dotyczy przyjęcia, że wszyscy uczestnicy sytuacji komunikacyjnych w instytucjach oświatowych mają równe prawa, niezależnie czy są uczniami, nauczycielami, rodzicami, czy studentami uczącymi się zawodu. Jeśli zgodzimy się z tym stwierdzeniem, musimy się wówczas zastanowić, co to oznacza w czasie, gdy jesteśmy w trakcie procesu stawania się kimś (np. nauczycielem), a ponadto, w jaki sposób możemy stać się świadomymi naszego rozumienia świata i uczenia się możliwych sposobów stawania się podmiotami ${ }^{13}$. Jak już wspomniano, jednostka nigdy nie tworzy sama własnej pozycji, ale warunki jej funkcjonowania zawsze są negocjowane w zbiorowych kontekstach społecznych. Dzięki wykorzystaniu zbiorowej pamięci wspólnie przeżytych doświadczeń oraz posiadanych $w$ danej grupie reprezentacji danego zjawiska (obiektu), ZPB pozwala na rozpoznanie, jak działają siły społeczne, gdy jednostka jest „społecznie zatwierdzona/usankcjonowana i pozycjonowana"14.

\section{Przebieg i organizacja badania ${ }^{15}$}

Narracja wykorzystana do zilustrowania omawianej metody nie była poddana pełnej analizie $w$ ramach procesu $\mathrm{ZPB}$, ponieważ taka wymaga długiego czasu realizacji. W literaturze dotyczącej tej metody mówi się o dwu-, trzysemestralnej pracy analitycznej ze studentami. Zajęcia ze studentami w polskich uczelniach trwają najczęściej jeden semestr, rzadko dwa. W tym artykule przedstawiam rezultaty pracy ze studentami po jednym semestrze. Dodać należy, że warsztaty ZPB trwały na każdych zajęciach po około 15-20 minut, a część pracy intelektualnej wykonywana była przez studentów jako zadanie domowe. Mimo swej niekompletności, sądzę, że podany przykład dobrze ilustruje rolę interpretacji w ZPB.

${ }^{12}$ M. Wihlborg, An Awareness of the Feminist Subject, s. 265.

13 Tamże, s. 260.

${ }^{14}$ M. Wihlborg, Using a Process of Collective Biography Writing in Higher Education to Develop an Ability to Explore, Reveal and Critically Reflect, European Educational Research Journal, 2013, 12(3), s. 376.

${ }^{15}$ Szczegółowy opis podstaw teoretycznych metody i procedury badawczej w ramach ZPB zawarłam w artykule: Z. Zbróg, Zbiorowe pisanie biografii jako poststrukturalistyczna metoda analizy wspomnień (Kwartalnik Pedagogiczny). 
Narracja o doświadczeniu w trakcie odbywania praktyki w klasie I czerpała z doświadczeń jednej osoby. Powstała jako ewokacja wspomnienia „,stawania się kimś", a następnie w trakcie procesu ZPB została przeredagowana na opowieść bardziej nasyconą emocjonalnie, bardziej ucieleśnioną. Należy zaznaczyć, że w metodzie ZPB wspomnienia zawsze pisane są w trzeciej osobie liczby pojedynczej czasu przeszłego, aby mogły być udostępniane w pamięci zbiorowej w czasie dalszych etapów pracy. Z całej opowieści wyodrębnia się po jej przeczytaniu najważniejszy fragment, który - zdaniem grupy - opisuje moment przełomowy, najważniejszy w danym epizodzie. Moment, który decyduje o takim, a nie innym rozwiązaniu sytuacji.

Warto także zwrócić uwagę na szczególną rangę, jaką nadaje się staranności używania języka w opisie epizodu autobiograficznego. $Z$ dużą precyzją, w sposób przemyślany poszukuje się sedna znaczenia konkretnych słów po to, aby wybrać takie określenia, które są najbardziej szczere/prawdziwe w stosunku do tego, co zapamiętaliśmy. Wszyscy starają się nie używać stereotypów czy wyjaśnień (wykładni). Dzięki pytaniom kierowanym do osoby opowiadającej następuje wstępne opracowanie historii. Zdania są kolejno odczytywane. W trakcie ich czytania "opowiadacz" stara się wyobrazić sobie dokładnie to samo, co czuł wtedy, gdy dana sytuacja odgrywała się realnie. Stara się przywołać u siebie obrazy i uczucia, wypowiedzieć do siebie słowa, które te uczucia wywołały, poczuć je. Te same uczucia/emocje powinny pojawiać się u słuchających jego opowieści. Jeśli więc tak się nie dzieje, trzeba zatrzymać się i wrócić do sedna znaczenia konkretnych słów, dobrać wspólnie takie (poprzez dopytywanie), które spowodują realne odczucie wrażeń/przeżyć opowiadacza także u innych. Ważne są więc egzemplifikacje opowieści oraz ilustrowanie jej przywoływanymi emocjami i wrażeniami zmysłowymi (np. zapachami), na przykład: Jak się czułaś, kiedy to się stało? Jakie zapachy temu towarzyszyły? Jakie wrażenia? Odnoszenie się do swoich odczuć i emocji daje pewność, że dochodzące do głosu wspomnienia są w jakiś sposób ucieleśniane, a dzięki tego typu nawiązaniom do swoich przeżyć będą łatwiejsze do wyobrażenia sobie i bardziej zrozumiałe dla innych w grupie. Wszyscy zgromadzeni badacze wsłuchują się w to, co mówi i co napisał w swoich wspomnieniach autor opowieści (wspomnień). Można powiedzieć, że wsłuchują się w siebie, analizując, jak sami odczuwają ten opis przedstawiany przez drugą osobę po to, aby poczuć go wewnątrz siebie, aby przeżyć dokładnie to samo, aby dostroić się do odczuć przeżywanych wcześniej przez narratora-,,opowiadacza”.

W poniższym przykładzie wątki opisujące sytuację-wspomnienie przeplatane są narracjami ucieleśnionymi, z zaakcentowanymi emocjami, jakie towarzyszyły bohaterce podczas epizodu. 
To byt pierwszy dzień jej praktyk, w którym miała pomagać nauczycielce w prowadzeniu zajęć z klasa I. Miała bardzo dużo energii i oczekiwań. Czuła się podekscytowana, szaleńczo szczęśliwa, że wreszcie spetni swoje marzenie i popracuje z dziećmi. Radość ją rozpierała tak bardzo, że najchętniej podskakiwałaby ze szczęścia pod sufit. Od zawsze chciała przecież być nauczycielka małych dzieci, od swojego przedszkola. Czuła się silna i zdolna podołać każdemu zadaniu. W głowie szumiało jej od przejęcia. Miała wrażenie, że wszystko jest nierealne. Wtaściwie sunęła korytarzem, myśląc o tym, jak magicznie się czuje. Przepetniało ją szczęście, nawet rozkosz, która powodowała odczucie nieokreślonych ciarek, mrowień pojawiajacych się na całym ciele w różnych miejscach, ale jednocześnie jakby podszycia nieokreślonym lękiem. Uda jej się. Spetni swoje marzenia.

Uśmiechnięta i przejęta weszła na zajęcia do klasy I i od razu zwróciła uwage na dwa rzędy tawek, które nie staty obok siebie, a byty oddzielone spora odległościa, która przedzielat dywan. Jeden rząd był przy biurku nauczycielki, a drugi przy samym oknie klasy. Początkowe zdziwienie zostato jednak szybko zastapione przez poczucie nadchodzacego spetnienia. Nie skupiała się na nim. Myślała o tym, że za chwile po raz pierwszy naprawdę będzie nauczycielka.

$\mathrm{Na}$ zajęciach zajęła miejsce obok prowadzącej lekcje. Miała w ten sposób ogląd na wszystkich uczniów. Chciata się jak najwięcej nauczyć, jak najwięcej przeżyć, chtonać wszystko wszystkimi zmystami.

Kiedy tylko nauczycielka zaczęła prowadzić zajęcia, z niedowierzaniem zorientowała się, że w rzędzie przy biurku siedza dzieci, które sa zdolne, dobrze radza sobie na lekcji, a drugi rząd zajmuja dzieci, które maja problemy z nauka. Wychowawczyni brała pod uwage tylko wypowiedzi dzieci, które siedziały w rzędzie przy niej.

Zaraz, zaraz... O co tu chodzi? - nie była w stanie przyjać do wiadomości tego, co widzi. Czy to dzieje się naprawdę???

Dzieci ciagle miaty raczki w górze, były chętne do wykonania zadania lub wypowiedzenia się na dany temat. Zauważyła, że chłopiec o imieniu Hubert, siedzacy w rzędzie przy oknie podnosit rączkę (wręcz wymachiwał nia), by móc również włączyć się w dyskusje prowadzona przez dzieci i nauczycielkę. Cały czas byt jednak ignorowany przez wychowawczynię. Nauczycielka była zainteresowana tylko wypowiedziami dzieci, które siedziaty w rzędzie przed nia, byta wręcz zachwycona i ciagle komentowała, jakich ona ma zdolnych uczniów, że tak intensywnie udzielają się na zajęciach.

Czuła się mocno poirytowana i niewypowiedzianie zdziwiona, gdyż pochwaty, które rozdzielata nauczycielka, były kierowane wyłacznie w stronę uczniów zdolniejszych. To niewiarygodne, że w dzisiejszych czasach zdarzaja się takie sytuacje! Skandal - to słowo cisnęło jej się do głowy. To niemożliwe! To niemożliwe!!! Całe jej ciało krzyczało. Nie mogła usiedzieć w miejscu. Kompletnie nie wiedziała, jak się zachować. Ma pomagać nauczycielce..., ale w czym? Jak? Nie chce pomagać W TYM. Za żadne skarby. Ucieczka! Ucieczka! Chce uciec! 
Dzieci siedzace w rzędzie przy oknie wygladaty na wycofane, mato zainteresowane zajęciami. Widać byto ich obawe przed zapytaniem lub poproszeniem o pomoc przy zadaniu. Nauczycielka rozwiazywała zadania z dziećmi zdolnymi, a dzieci słabe pytała tylko, czy już zrobity zadanie. Dzieci zawsze odpowiadały, że tak. Jednak gdy nauczycielka sprawdzała zadania i widziała braki w zeszytach ćwiczeń, nie była zadowolona. Z tego powodu używata określeń w stylu "Znowu nie nadążasz za catą klasa", "Czy z Toba zawsze musza być problemy?" lub "Przecież to zadanie jest takie proste. Czego w nim nie rozumiesz?" (często występowat tu ironiczny uśmiech), a następnie zostawiała dzieci same z problemem $i$ kazała dokończyć zadanie $w$ domu.

Zastanawiała się, dlaczego wychowawczyni nie pytała dzieci, z czym maja trudność, czego nie rozumieja, tylko pozostawiata dzieci z nierozwiązanym zadaniem. Caty dzień zaprzątała sobie głowę myślami na temat tej sytuacji. Nie mogła doczekać się, kiedy będzie mogła zajrzeć do sali, w której jej mama pracuje od kilkudziesięciu lat jako nauczycielka. Musiała się poradzić. Nie mogła dać sobie rady z czarnymi myślami, z szokiem! Mama również była zszokowana tym, co jej opowiedziała, ponieważ zna tę nauczycielkę i uważata ją za kompetentna i odpowiedzialna osobę. Matka podpowiedziała jej, jak ma postąić kolejnego dnia. Postanowiła to zrobić, chociaż była petna obaw, że wychowawczyni klasy I może się tym zdenerwować.

Kiedy nadszedt kolejny dzień, przyszła do szkoły parę minut przed rozpoczęciem zajęć, aby przygotować się i porozmawiać $z$ nauczycielka. Pani X siedziała już w klasie, więc od razu przeszła do sedna sprawy. Zapytała, czy mogłaby wprowadzić na lekcji małe zmiany, a mianowicie wymieszać dzieci zdolniejsze z tymi, które wykazuja problemy w nauce. W ten sposób uczniowie mogliby pomagać słabszym kolegom, a ci z kolei mogliby więcej skorzystać na zajęciach. Nauczycielka spojrzata na nia jak na wariatkę i z lekkim uśmiechem odpowiedziata: "Nie wyrażam na to zgody, gdyż uczniowie mogliby być zbyt zdezorientowani cata ta sytuacja i mogłoby to spowodować niekorzystne dla nich skutki". Wprost zagotowato jej się w brzuchu. Wściektość kipiata w jej wnętrznościach. Naprawdę miała ochotę trzepnać nauczycielkę w głowe albo złapać ja za ramiona i potrzasać tak, żeby się ocknęła, obudziła i zorientowała, co robi tym dzieciom, jaka straszna krzywdę im wyrządza. Przez ułamek sekundy zastanawiała się, co robić. Myśli biegły przez jej umyst w szaleńczym tempie. Bała się, strasznie się bała. Co robić? Jej ciało błyskawicznie samo podjęło decyzję. Usztywniła się, podniosta brodę do góry i .... nic nie powiedziała. Zachowała zimna krew i postanowiła oficjalnie nie podważać decyzji, pożal się Boże, "wychowawczyni". Była $z$ druzgotana $i$ zawiedziona decyzja wychowawczyni. Z premedytacja zajęcia przeprowadziła jednak tak, aby każda grupa dzieci była aktywna na zajęciach. Uczniowie $z$ uśmiechem na buziach rozwiazywali zadania przy tablicy, a tym, którzy sobie nie radzili, starała się pomóc z całą klasą. Widziała, że byli zachwyceni.

Była z siebie dumna. Patrzyła na "wychowawczynię" z wyższościa. 
W metodologii badań narracyjnych, w tym biograficznych, uważa się, że jeżeli poszukujemy głębszego zrozumienia dotyczącego tego, co się dzieje i jak możemy nauczyć się uczenia się o tym, co się dzieje, możemy stosować różne metody ${ }^{16}$. W metodzie ZPB, w powyższym przykładzie, nie chodzi tylko o to, aby zinterpretować, jak studentka uczyła się prowadzić zajęcia z dziećmi, ale jak my wszyscy uczymy się dowiadywania się o procesie uczenia się i kontekście tego uczenia się. Szczególne znaczenie ma refleksja podejmowana przez narratora, którego wspomnienie zostało wybrane do zbiorowej analizy. Jak twierdzi Agnieszka Niedźwieńska,

Zrozumienie przejścia od zdarzenia autobiograficznego do znajomości samego siebie wymaga odróżnienia przypominania od refleksji nad zdarzeniem. Pierwszy proces to wydobycie z pamięci, a mówiąc precyzyjniej jego zrekonstruowanie na podstawie przechowywanych elementów. Drugi proces wymaga czegoś więcej, a mianowicie wyjaśnienia i oceny zdarzenia. Jest to autorefleksyjne myślenie o własnej przeszłości (lub mówienie o niej), które obejmuje tworzenie powiązań między zdarzeniami i wiedzą na swój temat oraz odnoszenie własnej przeszłości do teraźniejszości ${ }^{17}$.

W ramach tej refleksji i wyjaśniania zdarzenia ktoś odpowiada sobie między innymi na pytania: Jak do niego doszło? Jak czuje się w zwiazku z tym, co się stało? Dlaczego tak się czuję?

Bronwyn Davies i Susanne Gannon ${ }^{18}$ omawiają zależność podmiotu od dyskursu i kontekstu, podkreślając, jak bardzo podmiot staje się bezbronny i bezradny wobec na przykład bycia nieuznawanym za kompetentnego lub w sytuacji wstrzymania uznania ze strony innych, jego ograniczenia lub nagłej utraty pewności co do przynależności do określonej grupy profesjonalistów. Studentka była przeświadczona o swojej kompetencji, więc zademonstrowała to, co było dla niej źródłem jej pewności i poczucia odpowiedzialności. W poststrukturalistycznej interpretacji danych, wzbogaconych o zmysłowe ucieleśnienia będące rezultatem przeprowadzenia procesu ZPB, następuje przesunięcie od wykazania się kompetencjami do pokazania tej kompetencyjności w kontekście. Jest nim demonstracja kompetencji w niesprzyjających okolicznościach, a może nawet wbrew nim.

\section{Przykład analizy poststrukturalistycznej - rezultat wspólnej pracy z grupą studentek}

Zdaniem grupy, pogłębione wspomnienie nauczycielki mówiącej do dziewczyny "Nie wyrażam na to zgody, gdyż uczniowie mogliby być zbyt zdezorien-

${ }^{16}$ M. Wihlborg, An Awareness of the Feminist Subject, s. 274.

17 A. Niedźwieńska, Wspomnienia, które nas tworza, [w:] Poznaj samego siebie, s. 106.

18 B. Davies, S. Gannon, Collective Biography. 
towani cała ta sytuacja $i$ mogłoby to spowodować niekorzystne dla nich skutki" ma kluczowe znaczenie dla dalszej interpretacji. To jest więc moment dyfrakcji, który w metodzie ZPB stosuje się zamiast (auto)refleksji. Refleksyjność, która stała się dogmatem badań jakościowych, nie sprawdza się podczas zbiorowej pracy ze wspomnieniami. Kiedy badacze ZPB próbowali uchwycić akt refleksji w trakcie warsztatów, okazało się to niemożliwe, ponieważ w wypadku pracy z grupą różnych osób przybierało to postać podobną do sali z lustrami, w której „oryginał” dzielił się na niezliczone wersje, tak naprawdę oddalające grupę od odkrycia tego co ważne. Okazało się, że refleksyjność zaciemnia obraz analizowanych wątków, wprowadza nas w błąd. W ZPB stosuje się więc dyfrakcję, która wymaga odczytania spostrzeżeń w sposób, który pomaga wyjaśnić różnice wyłaniające się w trakcie wspólnej pracy: jakie są te różnice, co zostanie przez nas wykluczone spośród wielu różnic, jakie znaczenie mają te wykluczenia. Idea dyfrakcji pokazuje, że wspólnie tworzone opowieści biograficzne uwydatniają, eksponują i ujawniają splątaną strukturę zmieniającej się i przypadkowej ontologii świata, w tym ontologii poznania. Uwikłania widać najlepiej w tym, co stanowi sedno wspomnień, ale także w praktykach, przez które są one generowane ${ }^{19}$.

Analityczne czytania w ZPB wykonywane są wspólnie, ale wszyscy muszą od czegoś zacząć. Ponowne odczytanie tego wspomnienia z uwzględnieniem liberalnych, humanistycznych kategorii przedstawia historię o samodzielnej i odpowiedzialnej dziewczynie, racjonalnym podmiocie, który jest przekonany, że to co robi jest słuszne. To, czego ta dziewczyna wcześniej się w życiu nauczyła, jej marzenia o pracy z dziećmi, ale nie z podejściem takim, jakie reprezentuje nauczycielka, ale z przeświadczeniem, że chce otwierać dla nich swoje serce i świat, spowodowały, że - mimo ewidentnej przeszkody, jaką jest postawa nauczycielki, jej brak uznania dla kompetencji studentki jawnie zademonstrowała credo swojej filozofii edukacyjnej. Podjęcie decyzji o braku otwartej konfrontacji z nauczycielką nie przeszkodziło jej w wyrwaniu się z zależności od opiekunki praktyk.

Poststrukturalistyczne odczytanie tego wspomnienia ukazuje relacyjny charakter bycia/stawania się podmiotu, realizowany w konkretnym dyskursie, uwzględniającym specyficzny czas, miejsce i przestrzeń, czyli kontekst, w którym to wszystko się działo.

Ucieleśniona specyfika tego wspomnienia mówi nam, że dziewczyna jest usytuowana jako mogąca działać autonomicznie i to nawet wbrew woli nauczycielki. Jest przekonana o tym, jest przeświadczona o takiej pozycji siebie jako podmiotu, ponieważ czuje nieodpartą chęć realizacji siebie i swojej wizji

${ }^{19} \mathrm{~K}$. Barad, Meeting the universe halfway: Quantum physics and the entanglement of matter and meaning, Durham 2007. 
pracy z dziećmi. Nie potrzebuje potwierdzenia i zgody nauczycielki. Konsekwentnie realizuje swój cel, wierząc mocno, że to jej postawa reprezentuje zachowanie właściwe dla dobrego nauczyciela. Metodycznie podchodzi więc do swoich zadań, starając się racjonalnie zrealizować swoje zamierzenia. Jej niezłomność i wytrwałość w urzeczywistnieniu swojej wizji ideału nauczyciela, mimo jawnej niechęci wychowawczyni, daje jej odwagę i śmiałość do spełnienia swoich celów. Czuje się silna i władna przeciwstawić się (choć niejawnie) osobie, która z jej perspektywy wydaje się nieodpowiedzialna, bezmyślna, szkodząca dzieciom.

Pozycja podmiotu ujawniająca się $\mathrm{w}$ tym wspomnieniu jest osadzona $\mathrm{w}$ indywidualnych dyskursach kompetencji i autonomii. Ona sama pośrednio dowodzi „bycia” w dyskursie relacyjności i niezawodności kompetencyjnej. Wspomnienie mówi nam, że inne podmioty pojawiające się w tej historii wzajemnie wpływają na siebie (nauczycielka mówiąca Nie wyrażam na to zgody) w taki sposób, że sprzeciw jednego podmiotu powoduje tym bardziej dążenie drugiego podmiotu do ujawnienia swojej decyzyjności. Dzięki temu dziewczyna mogła - wbrew niekorzystnym okolicznościom ujawnić się jako podmiot autonomiczny. Mogła sobie wyobrazić siebie (Była zdruzgotana $i$ zawiedziona decyzja wychowawczyni. Była z siebie dumna.) jako osobę odpowiedzialną za ostateczne rozwiązanie tej sytuacji, mimo obaw, a nawet strachu, który towarzyszył jej w trakcie podejmowania decyzji, co dalej. Była przekonana o słuszności swojej postawy, co utwierdzało ją $\mathrm{w}$ przekonaniu, że dla dobra dzieci powinna zaryzykować niezadowolenie wychowawczyni.

To wspomnienie jest przykładem bycia w pozycji samodzielnego, odpowiedzialnego, autonomicznego podmiotu. Ona jest przekonana o słuszności swojego podejścia, a reakcje dzieci na prowadzone przez nią zajęcia wywołują u niej pewność, że jej postawa nie może być zakwestionowana, nawet przez „wychowawczynię". To nie jest przypadek, że dzieci są zachwycone jej podejściem.

Jedynie poprzez relacyjny charakter tego doświadczenia, wynikający z jednej strony ze stosunku (i/lub zależności) z nauczycielką i dziećmi, mogła doświadczyć uznania ze strony dzieci. To uznanie ma prawdziwą wartość tylko w tym specyficznym kontekście, w istotności jej interakcji z innymi czy też $\mathrm{w}$ stosunku do innych.

Odbierając informacje od nauczycielki i reagując na nie, dziewczyna uzmysławia nam, że ten interaktywny charakter ruchu/przemieszczenia pomiędzy całym wspomnieniem i jego szczegółami składającymi się na tę narrację ujawnia zależność podmiotu w dyskursie (to jest właśnie sedno orientacji poststrukturalistycznej). Ten przykład ukazuje nam głębię 
zależności dziewczyny od dyskursu uznania (jej kompetencji). Zależność ta stoi w sprzeczności z samotnością, autonomią i niezależnością jednostki, która nie ma jeszcze doświadczenia w pracy z dziećmi. Zależność od uznania innych, jej formalne podporządkowanie władzy nauczycielki jest kontrastowane z jej osobistymi przekonaniami i wizjami ideału nauczyciela oraz nieformalnym, ale zdecydowanym wyartykułowaniem swojej filozofii edukacyjnej.

Można uznać, że dziewczyna zachowała się tak, jak się zachowała, dzięki koncepcji samej siebie bazującej na sile, przekonaniu o własnej racji i niezgodzie na niesprawiedliwe, nierówne traktowanie innych.

Emocjonalny opis tego zdarzenia i jego wielokrotne przywoływanie (na zasadzie przypomnienia) pozwala zrozumieć, kim się jest. Sens zdarzenia sprowadza się do ukierunkowania przyszłego zachowania dziewczyny (być może także innych uczestników warsztatów) w podobnych sytuacjach. Implikacją szerszą jest wiedza o sobie, innej ważnej osobie lub relacjach z innymi ludźmi.

\section{Analiza korzyści dla grupy}

Analityczne czytanie tekstu pozwoliło uświadomić całej grupie, w jaki sposób zachowanie studentki zachwiało dyskursem podporządkowania w relacji praktykant-nauczyciel. Studenci automatycznie odkryli i ujawnili warunki/okoliczności czyjegoś podporządkowania, dzięki czemu stały się one czytelne i widoczne dla całej grupy pracującej metodą ZPB, a sama niepisana zasada podporządkowania uległa zakłóceniu, stała się kategorią bardziej przystępną w świadomości przyszłych nauczycieli. Zobaczyli oni, jak kontekst może kształtować tę dziewczynę jako „odpowiedniego rodzaju" studentkę. Odkryli także, skąd bierze się siła dziewczyny. Z pewnością uświadomienie sobie tego będzie niosło ze sobą konsekwencje dla przyszłego zachowania studentów na praktykach, dla oglądu przez nich swojej sytuacji i swojej pozycji w dyskursie władza-wiedza w relacjach z nauczycielami. Pragnienie akceptacji, uznania swoich kompetencji przez studentów może bowiem doprowadzić do zupełnie odmiennego zachowania się w takich okolicznościach.

Na tym etapie pracy metodą ZPB uwidacznia się, w jaki sposób i w jakim stopniu jesteśmy zawsze uwikłani w powtarzalne praktyki (konkretne sposoby wykonywania jakiejś czynności, patrzenia na daną sytuację). Zrozumienie tego daje możliwość uchwycenia przejawiających się wówczas wątków dyskursu prywatnego i publicznego, odsłaniając przykłady ambiwalencji, dwuznaczności, czy niejednoznaczności. Mamy wtedy do czynienia z widzeniem 
w tym samym czasie typowych sposobów postrzegania jako „sposobu widzenia" oraz widzeniem na przekór tym zwykłym sposobom ${ }^{20}$.

Przystępność analizy dyskursu podporządkowania i okoliczności podporządkowania sobie innych w nierównoprawnych relacjach stanie się podstawą dalszych przemyśleń, być może także zmiany przekonań studentów, które będą miały pozytywny wpływ na ich przyszłe funkcjonowanie (nie tylko w zawodzie nauczyciela). Tym bardziej że różnego rodzaju „zakłóceń” w rzeczywistości szkolnej i przedszkolnej jest wiele. Tego typu analiza pokazuje studentom, że podmiot może utrzymać swoją nieelastyczną/stałą pozycję w życiu, nawet w sytuacjach wielkiej różnorodności.

Dzięki podkreśleniu różnic w zachowaniu obu bohaterek opowieści mamy możliwość odkrywania/konstruowania nowych znaczeń w wielu obszarach. Podczas pracy z wykorzystaniem ZPB rozwijanie krytycznej zdolności rozpoznawania i identyfikacji różnic jest jednym z najważniejszych zadań. Zbiorowe poszukiwanie możliwych scenariuszy, momentów, ilustracji lub scen jest centralną częścią procesu ZPB. To otwiera możliwość stania się świadomym tych różnic i uzmysłowienia sobie różnic jako fenomenu. Studenci mogli odpowiedzieć na pytania: Co konstytuowało podmiotowość dziewczyny? Jak przejawiata się jej wewnętrzna walka pomiędzy chęcia bycia uznana przez nauczycielkę za osobę kompetentna i chęcia bycia uznana przez dzieci? Co zdecydowato o podjęciu decyzji wyrwania się z zależności od opiekuna praktyk? Co spowodowato o takim, a nie innym przebiegu opowieści? Skąd wzięta się jej siła do walki, niezgoda na narzucone warunki? Skąd bierze się uległość? Dlaczego sie poddajemy?

Odpowiedzi studentów na powyższe pytania są dla nich ważne, ponieważ - jak wskazuje praktyka - są oni często "nawracani na właściwą ścieżkę" przez nauczycieli-opiekunów, na ścieżkę pracy metodami tradycyjnymi, bazującymi na przebrzmiałych tezach behawioryzmu.

W literaturze pedeutologicznej często podkreśla się, że osadzony w paradygmacie transmisji kulturowej sposób pracy nauczycieli nie zmieni się, jeśli przyszli nauczyciele nie będą kształceni w inny sposób, umożliwiający zmianę przekonań na temat zawodu nauczyciela i pełnionych przez niego funkcji. Najlepszym momentem do uświadomienia ukrytych uwarunkowań funkcjonowania edukacji i pełnienia roli zawodowej nauczyciela jest zwrócenie uwagi studentom - przyszłym nauczycielom na społeczną konstrukcję własnego Ja, na możliwość jego zmiany/ przemiany, dzięki której mamy możliwość stania się krytycznie świadomymi siebie i swoich działań/zachowań $\mathrm{w}$ celu zakwestionowania tego, co powszechnie uznawane jest za pewnik i oczywistość. Permanentne uczenie się siebie, świata, podejmowanie prób

\footnotetext{
${ }^{20}$ B. Davies, S. Gannon, Collective Biography.
} 
zrozumienia swoich decyzji, znajdowania uzasadnień, doszukiwania się znaczenia swoich działań pedagogicznych dla dzieci jest kluczowym warunkiem zmiany swoich przekonań, swoich reprezentacji o pracy nauczyciela.

\section{Wnioski}

Kontekstowość zapamiętanego zdarzenia, okoliczności, do których nawiązują wspomnienia są źródłem konstruowania tożsamości nie tylko jednostki, ale całej grupy, całej społeczności egzystującej w podobnych warunkach. W trakcie ZPB uczestnicy zastanawiają się, jakie siły kształtowały daną sytuację, co powoduje, że dzieje się tak, jak się dzieje. Jakie uwarunkowania zewnętrzne (polityka, ekonomia, władza, wiedza, kontekst sytuacyjny) i wewnętrzne (np. cechy osobowościowe) decydowały o takim, a nie innym przebiegu opowieści. Warsztaty ZPB eksplorują uwikłania spraw i znaczenia, przez które jesteśmy wspólnie zaangażowani w tworzenie naszych warunków do rozwoju, do stawania się nauczycielami. Dzięki warsztatom ZPB studenci dogłębniej uświadamiają sobie swoją pozycję w procesie uczenia się oraz wartość różnego rodzaju różnic, które pojawiają się w trakcie przygotowania do zawodu nauczyciela.

ZPB pozwala dotrzeć do dostępnego nam repertuaru tworzenia znaczeń, dzięki którym coś (np. nasze działanie) nabiera sensu lub przeciwnie - tego sensu nie ma. Najważniejszą zaletą ZPB jest jednak to, że metodologia ta pozwala na odkrycie, czego jeszcze nie znamy, nie dostrzegamy bez dokładniejszych analiz ani u siebie, ani w świecie. Możliwości dostrzeżenia tych głębszych uwarunkowań są nam dostępne tylko dzięki wspólnej zaangażowanej pracy nad własnymi wspomnieniami.

W dokumentach związanych z procesem bolońskim podkreśla się znaczenie umiejętności rozwijania $w$ trakcie studiów wyższych krytycznego myślenia i zdolności do krytycznej refleksji ${ }^{21}$. Stosowanie na zajęciach ze studentami metody ZPB nie tylko wypełnia ten warunek, bowiem krytyczne podejście do analizowanych zjawisk jest kluczowe w tej metodzie, ale także stanowi jeden z rezultatów wykorzystywania tej metody praktycznie. Pokazuje studentom, jak można analizować zjawiska i doświadczenia, które są ich udziałem $w$ życiu codziennym, w tym na praktykach pedagogicznych lub na zajęciach uczelnianych. Wspólna praca nad redagowaniem narracji uświadamia studentom niejednoznaczność wielu zdarzeń, uwrażliwia ich na różne rozumienie rozmaitych aspektów życia, w wypadku zajęć na

${ }^{21}$ http://www.ekspercibolonscy.org.pl/sites/ekspercibolonscy.org.pl/files/2009_PL_Leuven_Louvain-la-Neuve.pdf 
uczelni, głównie życia studenckiego i nauczycielskiego, związanego z dylematami pedagogicznymi, z rozumieniem zjawisk edukacyjnych, których nieodłączną cechą jest niejednoznaczność i niepewność.

\section{BIBLIOGRAFIA}

Barad K., Meeting the universe halfway: Quantum physics and the entanglement of matter and meaning, Duke University Press, Durham NC 2007.

Davies B., Gannon S., Collective Biography and the Entangled Enlivening of Being, International Review of Qualitative Research, 2012, 5, 4, s. 357-376.

http://www.ekspercibolonscy.org.pl/sites/ekspercibolonscy.org.pl/files/2009_PL_Leuven_Louvain-la-Neuve.pdf

Onyx J., Small J., Memory-Work: The Method, "Qualitative Inquiry", 2001, 7, 6, s. 773-785 (dostępne w pdf).

Mias C., Training and Ruptures, [w:] Education, Professionalization and Social Representations, red. M. Chaib, B, Danermark, S. Selander, Cambridge University Press, New York London 2013.

Moscovici S., Social Representations. Explorations in Social Psychology, Polity Press, Cambridge 2000.

Neckar J., Samowiedza i jej bohater, [w:] Poznaj samego siebie, red. A. Niedźwieńska, J. Neckar, Academica, Warszawa 2009.

Niedźwieńska A., Wspomnienia, które nas tworza, [w:] Poznaj samego siebie, red. A. Niedźwieńska, J. Neckar, Academica, Warszawa 2009.

Wagoner B., Collective remembering as a process of social representation, [w:] The Cambridge Handbook of Social Representations, red. G. Sammut, E. Andreouli, G. Gaskell, J. Valsiner, Cambridge University Press, Cambridge 2015.

Wihlborg M., Using a Process of Collective Biography Writing in Higher Education to Develop an Ability to Explore, Reveal and Critically Reflect, European Educational Research Journal, 2013, 12(3).

Wihlborg M., An Awareness of the Feminist Subject: An Example of Collective Biography Writing in Poststructuralist Discourse Practice, [w:] International Handbook of Interpretation in Educational Research, red. P. Smeyers, D. Bridges, N.C. Burbules, M. Griffiths, Springer, Dordrecht - Heidelberg - New York - London 2015. 